DUNAMIS (Jurnal Teologi dan Pendidikan Kristiani)

Volume 1, Nomor 2, April 2017

ISSN 2541-3937 (print), 2541-3945 (online)

http://www.sttintheos.ac.id/e-journal/index.php/dunamis

Submit: 04 April 2017

Accept: 29 April 2017

Publish: 30 April 2017

\title{
Penerapan Metode Demonstrasi untuk Meningkatkan Hasil Belajar Pendidikan Agama Kristen Materi Pembelajaran Sakramen Perjamuan Kudus VIII SMP Negeri 17 Surakarta, Tahun 2015/2016
}

\author{
Rifai \\ Sekolah Menengah Pertama Negeri 17 Surakarta \\ kangmasrifai@gmail.com
}

\begin{abstract}
This article aims to increase affective, psychomotor and cognitive domain of learning achievement with subject Sakramen Perjamuan Kudus for students grade VIII in State Junior High School 17 Surakarta at semester 2, year 2015/2016 by using demonstration method. This article used a method of clasroom action research which subject is all Christian students of grade VIII State Junior High School 17 Surakarta, year 2015/2016. The research found affective domain increasing from $14.1 \%$ at first cycle to $92.4 \%$ at second cycle. There were increasing up to $85.3 \%$ in psychomotor domain at second cycle, which means students resulted is accomplished, because it gained $0.3 \%$ over $85 \%$ achievement indicator. In cognitive domain increasing tehre were 15 (88.2\%) students at second cycle accomplished, which over than $85 \%$. Those were indicated that demonstration method usage to improve learning was success. By the result of this research, author recommends teacher will use demonstration learning method in teaching subject Sakramen Perjamuan Kudus.
\end{abstract}

Keywords: learning result; subject of Perjamuan Kudus; demonstration method; Christianity Education

\begin{abstract}
Abstrak
Penelitian ini bertujuan untuk meningkatkan hasil belajar afektif, psikomotorik dan kognitif materi Sakramen Perjamuan Kudus bagi peserta didik kelas VIII SMP Negeri 17 Surakarta semester 2 Tahun 2015/2016 melalui metode demonstrasi. Metode penelitian tindakan kelas menggunakan subyek adalah siswa Kristen kelas VIII SMP Negeri 17 Surakarta tahun ajaran 2015/2016. Dari penelitian didapatkan peningkatan hasil belajar afektif dari $14,1 \%$ menjadi 92,4\%. Pada hasil belajar psikomotorik siklus kedua mencapai 85,3\%, yang berarti ada peningkatan sebesar $0,3 \%$ di atas indikator pencapaian $85 \%$. Peningkatan hasil belajar kognitif pada siklus kedua mendapatkan hasil sebanyak 15 peserta didik $(88,2 \%)$ tuntas. Ketuntasan ini menandakan bahwa perbaikan pembelajaran pada siklus kedua dengan menggunakan metode demonstrasi dinyatakan berhasil. Dari Hasil penelitian tindakan kelas ini maka peneliti merekomendasikan penggunaan metode demonstrasi untuk mengajarkan materi Sakramen Perjamuan Kudus.
\end{abstract}

Kata kunci: hasil belajar; materi Perjamuan Kudus; metode demonstrasi; Pendidikan Agama Kristen

172 Copyright@ 2017, DUNAMIS, ISSN 2541-3937 (print), 2541-3945 (online) 


\section{PENDAHULUAN}

Teknologi dan globalisasi yang berkembangan pesat dan maju memberikan pengaruh perubahan terhadap pembentukan watak dan kepribadian seseorang, baik secara positif maupun negatif. Pengaruh positif teknologi dan globalisasi pada pribadi manusia telah membawa kehidupan manusia ke taraf kehidupan yang lebih mapan menghadapi era globalisasi yang berkembang pesat. Akan tetapi pengaruh negatif juga tidak dapat dihindarkan dalam mempengaruhi kehidupan moral. Pendidikan Agama Kristen salah satu bagian dari disiplin ilmu memiliki materi dalam merealisasikan tujuan nasional tersebut di atas. Namun sayang Pendidikan Agama Kristen belum mendapatkan perhatian serius dari pemerintah, dimana setiap minggunya hanya 2 jam pelajaran.

Menurut Tim Pengembang Ilmu Pendidikan FIP-UPI, sebagaian besar umat beragama dalam memandang agamanya hanya sebatas masalah ritual dan segi-segi formalitas dalam agama. ${ }^{1}$ Seolah apa yang disebut agama adalah seperangkat gerakan dan bacaan-bacaan serta doa-doa dalam ritual sembahyang dan ibadat. Tindakan ritual dan segi-segi formalitas agama itu baru mempunyai makna hakiki jika mampu mengantarkan seseorang kepada tujuannya

\footnotetext{
${ }^{1}$ Tim Pengembang Ilmu Pendidikan FIP - UPI, Ilmu dan Aplikasi Pendidikan (Jakarta: Grasindo, 2007), IV: 6
}

yang hakiki pula yaitu kedekatan kepada Tuhan sehingga memiliki kesiapan emosional dan spiritual dalam menjalani hidup di dunia.

Pendekatan pembelajaran yang tepat dalam Pendidikan Agama Kristen guna menjembati unsur normatif dan formalitas agama merupakan tugas besar sekolah dan guru di lapangan. Kurangnya kreativitas dan sikap inovatif seorang guru agama dapat menyebabkan pelaksanaan pembelajaran Pendidikan Agama Kristen bersifat monoton. Pendekatan pembelajaran sangat besar pengaruhnya dalam penerimaan pemahaman materi pembelajaran, sebagaimana data dalam pra siklus penelitian tingkat keberhasilan klasikal sebesar $23,5 \% \quad(4 \quad$ siswa). Rendahnya pemahaman materi Sakramen Perjamuan Kudus masih jauh dari indikator keberhasilan yakni $85 \%$.

Strategi demontrasi merupakan pendekatan dalam proses belajar mengajar dapat memberikan pengaruh tiga hal seperti dikatakan oleh Jalaluddin Rakhmat (2007: 39) maksimalisasi pengaruh tubuh terhadap jiwa, maksimalisasi pengaruh jiwa terhadap proses psikofisik dan psikososial, serta bimbingan ke arah pengalaman mistik. Untuk memaksimalkan pengaruh "tubuh", banyak metode dapat dikembangkan. Di sini, kita hanya menyebut berapa saja, lingkungan fisik yang menyenangkan, 
penggunaan musik, dan penggunaan latihan-latihan fisik (physical exercises) yang menimbulkan kepercayaan diri.

Penelitian tindakan kelas in berupaya menemukan model pendekatan pembelajaran yang tepat untuk diterapkan sebagai metode atau strategi dalam proses pembelajaran Pendidikan Agama Kristen di SMP Negeri 17 Surakarta. Adapun permasalahan penelitian ini adalah: Apakah penerapan metode demonstrasi dapat meningkatkan hasil belajar afektif, psikomotorik dan kognitif pada materi Sakramen Perjamuan Kudus bagi peserta didik kelas VIII SMP Negeri 17 Surakarta semester 2 Tahun 2015/2016? Dengan demikian, maka tujuan penelitian ini jelas, yaitu: Untuk meningkatkan hasil belajar afektif, psikomotorik dan kognitif materi Sakramen Perjamuan Kudus bagi peserta didik kelas VIII SMP Negeri 17 Surakarta semester 2 Tahun 2015/2016 melalui metode demonstrasi.

\section{Metode Demonstrasi}

\section{Definisi Metode Demonstrasi}

Metode demonstrasi adalah proses pembelajaran dengan cara menyajikan materi pembelajaran dengan memperagakan atau mempertunjukkan kepada peserta didik suatu proses yang sedang dipelajari. Dalam mendemonstrasikan juga dapat menggunakan benda atau alat tertentu, baik benda atau alat yang sesungguhnya ataupun yang berupa tiruan, namun perlu adanya penjelasan lisan.

\section{Teori Belajar Sosial}

Suyono dan Hariyanto (2011: 67-68) menjelaskan tahapan modelling sebagai berikut $^{2}$ : Atensi, retensi, produksi dan motivasi. Atensi (perhatian) adalah mempelajari sesuatu dengan memperhatikannya secara saksama, berkonsentrasi, jangan banyak hal yang menganggu pikiran. Retensi (ingatan) adalah, mengingat apa yang telah diperhatikan dengan seksama tadi. Produksi berarti kita hanya perlu duduk dan membayangkan untuk dapat menerjemahkan uraian/deskripsi model ke dalam perilaku aktual. Aspek yag paling penting adalah kemampuan improvisasi dalam membayangkan diri sebagai model.

Sedangkan motivasi adalah dorongan atau alasan-alasan tertentu untuk berbuat meniru model. Dorongan itu bisa dalam bentuk dorongan masa lalu, dorongan yang dijanjikan (insentif) yang dapat kita bayangkan, dan (iii) dorongan-dorongan yang kentara (tangible) seperti melihat/mengingat model-model yang patut ditiru.

\footnotetext{
${ }^{2}$ Suyono dan Hariyanto, Belajar dan Pembelajaran (Bandung: PT Remaja Rosdakarya, 2011), 67-68
} 


\section{Manfaat Metode Demonstrasi}

Muhibbin Syah mengungkapkan adanya faktor asumsi psikologis yang melatarbelakangi perlunya penggunaan metode demonstrasi adalah proses melakukan dan mengalami sendiri (learning by doing dan experiencing) apaapa yang dipelajari. ${ }^{3}$ Ns. Roymond Simamora menambahkan perihal manfaat psikologis metode demonstrasi bahwa: 1) Perhatian peserta didik dapat lebih dipusatkan; 2) Proses belajar peserta didik terarah pada materi yang sedang dipelajari; 3) Pengalaman dan kesan sehingga hasil pembelajaran lebih melekat dalam diri peserta didik. ${ }^{4}$ Dengan kata lain, metode demonstrasi memberikan kesempatan kepada siswa mengamati tahapan yang akan dikerjakannya dalam melakukan sebuah proses atau keterampilan.

\section{Langkah-langkah Metode Demonstrasi}

Beberapa langkah untuk menerapkan metode demonstrasi, seperti yang diusulkan oleh Andayani ${ }^{5}$ dan Suyatno ${ }^{6}$ adalah sebagai berikut:

\footnotetext{
${ }^{3}$ Muhibbin Syah, Psikologi Pendidikan (Bandung: PT Remaja Rosdakarya, 2010), 205

${ }^{4}$ Simamora, Ns. Roymond H. Simamora.. Buku Ajar - Pendidikan dalam Keperawatan (Jakarta: Penerbit Buku Kedokteran EGC, 2008), 57

${ }^{5}$ Andayani, Problema dan Aksioma (Yogyakarta: CV. Budi Utama, 2015), 249

${ }^{6}$ Suyatno, Menjelajah Pembelajaran Inovatif (Jawa Timur: Masmedia Buana Pustaka, 2009), 127
}

1) Guru menyampaikan kompetensi yang dicapai (Tujuan Pembelajaran Khusus/TPK)

2) Guru menyajikan gambaran sekilas materi yang akan disajikan.

3) Menyiapkan bahan/alat yang diperlukan, menunjuk salah seorang atau beberapa siswa untuk mendemonstrasikan semua skenario yang telah disiapkan.

4) Seluruh siswa memperhatikan demonstrasi dan menganalisisnya.

5) Tiap siswa mengemukakan hasil analisanya dan juga pengalaman siswa didemonstrasikan.

6) Guru bersama siswa membuat simpulan.

\section{Hasil Belajar}

Belajar adalah kegiatan atau aktivitas seorang siswa melalui bimbingan guru, orang tua ataupun mandiri untuk mendapatkan pengetahuan, pengalaman dan keterampilan. Guru memiliki peran penting dalam membantu siswa untuk belajar lebih terarah dengan hasil yang lebih baik lagi. Tim Pengembang Ilmu Pendidikan FIP UPI mengatakan belajar dewasa ini dikonotasikan dengan perubahan tingkah laku (Change Behavior). ${ }^{7}$ Dengan demikian yang dimaksudkan dengan hasil belajar dalam penelitian ini adalah perubahan tingkah laku yang diharapkan dari siswa

\footnotetext{
${ }^{7}$ FIP - UPI, Ilmu dan Aplikasi Pendidikan, 328
} 
setelah menjalani aktivitas melalui bimbingan guru, orang tua ataupun mandiri.

Berkaitan dengan hasil belajar, ada tiga tipe hasil belajar. Pertama, tipe hasil belajar kognitif yakni pengetahuan hafalan termasuk pula pengetahuan yang sifatnya faktual, di samping pengetahuan mengenai hal-hal yang perlu diingat kembali. ${ }^{8}$ Tipe belajar kognitif dalam pencapaiannya diukur melalui evaluasi kognitif. Keberhasilan siswa yang berdimensi kognitif (ranah cipta) dapat diukur dengan berbagai cara, tes tertulis maupun tes lisan dan perbuatan. ${ }^{9}$

Tipe hasil belajar yang kedua adalah afektif, yakni berkenaan dengan sikap dan nilai. Tipe hasil belajar afektif tampak pada siswa dalam berbagai tingkah laku seperti perhatian terhadap pelajaran, disiplin, motivasi belajar, menghargai guru dan teman sekelas, kebiasaan belajar dan lainlain. ${ }^{10}$ Tipe hasil belajar afektif dalam pencapaiannya diukur melalui evaluasi prestasi afektif. Dalam merencanakan penyusunan instrumen tes prestasi siswa berdimensi afektif (ranah rasa) jenis-jenis prestasi internalisasi dan karakteristik seyogianya dapat perhatian khusus. ${ }^{11}$ Alasannya, kedua jenis ranah rasa itulah

\footnotetext{
${ }^{8}$ Nana Sudjana, Dasar-dasar Proses Belajar Mengajar (Bandung: Sinar Baru Algensindo, 2009), 50

${ }^{9}$ Syah, Psikologi Pendidikan, 151

${ }^{10}$ Sudjana, 53

${ }^{11}$ Syah, 152
}

yang banyak mengendalikan sikap dan perbuatan siswa.

Ketiga adalah tipe hasil belajar psikomotorik, yang tampak dalam bentuk keterampilan (skill), kemampuan bertindak individu. ${ }^{12}$ Hasil belajar psikomotorik dalam pencapaiannya diamati melalui observasi. Cara pandang tepat untuk mengevaluasi keberhasilan belajar yang berdimensi ranah psikomotorik (rasa krasa) adalah observasi. ${ }^{13}$ Observasi, dalam hal ini dapat diartikan sebagai sejenis tes mengenai peristiwa, tingkah laku, atau fenomena lain, dengan pengamatan langsung.

\section{Sakramen Perjamuan Kudus}

Sakramen berasal dari bahasa Latin: sacramentum, yang artinya kudus, suci atau rahasia. Arti lain dari kata sakramen adalah "bahasa isyarat" dari Tuhan. Bahasa isyarat bersifat universal dan menggunakan bahasa simbol seperti air, roti, minyak dan juga tindakan-tindakan tertentu untuk berbicara secara langsung kepada jiwa kita. Bahasa isyarat yang digunakan Tuhan memiliki kuasa untuk mengubah orang yang menerimanya.

\section{Latar Belakang}

Dalam keyakinan iman Kristen terdapat dua sakramen, yakni Baptisan Kudus dan Perjamuan Kudus; kedua-duanya 
dilayankan dalam persekutuan jemaat. Sakramen yang dilayankan dalam gereja merupakan ketetapan yang diperintahkan Tuhan Yesus kepada para pengikut-Nya. Tuhan Yesus menetapkan Baptisan Kudus pada peristiwa baptisan di sungai Yordan (Mat. 28 : 19-20). Dan Tuhan Yesus juga menetapkan Perjamuan Kudus supaya dilayankan dalam gereja sebagai "peringatan" akan Dia sampai Ia datang kembali. (Mat. $26: 29$; Mark. $14: 25 ; 1$ Korit.11 : 26).

\section{Fungsi bagi Orang Percaya}

Pertama, perjamuan kudus sebagai pengucapan syukur atas penebusan dosa. Dalam konteks Perjanjian Lama, malam Paskah atau yang seringkali dipahami dengan istilah Perjamuan Malam Terakhir dirayakan sebagai peringatan kemenangan Israel dari perbudakan bangsa Mesir. Demikian juga dalam Perjamuan Kudus, orang percaya mendapatkan undangan dari Tuhan Yesus untuk datang dalam pesta kemenangan atas dosa dan maut.

Kedua, untuk memperingati sengsara dan kematian Kristus. Roti dan anggur sebagai lambang tubuh dan darah Kristus. Pada saat Tuhan Yesus melakukan Perjamuan Malam Terakhir bersama para murid-Nya, menurut kesaksian Firman Tuhan (Luk. 19:15-20; 1 Kor. 11:23-34). "Tubuh" dan "darah" diartikan kematianNya segera di kayu Salib, tatkala
tubuh-Nya akan diremukkan (lihat Yoh. 19:31-37) dan darah-Nya ditumpahkan dalam kematianNya yang mengerikan. Rasul Paulus mengatakan dalam 1 Korintus 23-34, "Inilah tubuhKu yang diserahkan bagi kamu; perbuatlah demikian menjadi peringatan akan Aku!"

Ketiga, Perjamuan Kudus sebagai perjamuan persekutuan di surga. Ketika Tuhan Yesus melaksanakan Perjamuan Kudus bersama-sama dengan muridmuridNya, Ia berkata : "Mulai dari sekarang Aku tidak minum lagi hasil pokok anggur ini sampai hari Aku meminumnya, yaitu yang baru bersama-sama dengan kamu dalam Kerajaan BapaKu" (Mat. 26 : 29 ; Mark. 14 : 25). Perjamuan Kudus selain sebagai petunjuk jalan keselamatan orang percaya juga merupakan jalan pengharapan orang percaya dalam Perjamuan Kudus di surga bersama Kristus (Why. 2:7; 21:7).

Keempat, persekutuan dengan sesama orang percaya. Dalam melaksanakan Perjamuan Kudus, setiap anggota jemaat atau orang percaya berkumpul bersama dan merayakan Perjamuan Kudus dengan sukacita bersama. Persekutuan orang percaya bukan hanya dengan Kristus yang mati dan yang bangkit, akan tetapi juga dengan Kristus yang dimuliakan dan dengan Kristus yang akan datang kembali. Karena itu dasar dari perayaan Perjamuan 
Kudus adalah orang percaya yang telah dipersekutukan dengan "Tubuh dan darah" (1 Kor. 11 : 23 dst) dan melalui Perjamuan Kudus yang mempersekutukan jemaat, sehingga kita telah menjadi milik Kristus.

Hipotesis tindakan yang diajukan dalam penelitian ini adalah: Penerapan metode demonstrasi dapat meningkatkan hasil belajar afektif, psikomotorik dan kognitif, materi Sakramen Perjamuan Kudus bagi peserta didik kelas VIII SMP Negeri 17 Surakarta semester 2 Tahun 2015/2016.

\section{METODE}

\section{Instrumen Penelitian}

Instrumen observasi dalam penelitian ini berupa lembar observasi terstruktur (halhal yang akan dinilai atau data yang akan dikumpulkan terterah dalam lembar observasi). Instrumen dokumentasi digunakan untuk mengumpulkan dokumendokumen yang berkaitan dengan penelitian tindakan kelas ini seperti foto-foto kegiatan, rekaman, ataupun dokumen-dokumen pendukung penelitian.

Instrumen tes berupa tes kecil yang dilakukan pada saat proses belajar mengajar berlangsung. Instrumen tes digunakan untuk mengetahui peningkatan hasil belajar yang dicapai oleh peserta didik.

\section{Teknik Pengumpulan Data}

Teknik pengumpulan data dalam penelitian adalah: teknik dokumentasi, observasi, wawancara, dan teknik tes tertulis. Teknik dokumentasi digunakan untuk mencatat semua arsip dan dokumen berupa foto-foto kegiatan, profil SMP Negeri 17 Surakarta, daftar hadir, hasil belajar siswa dan dokumen yang berkaitan dengan penelitian tindakan kelas ini. Teknik observasi dilaksanakan secara langsung, terfokus dan selektif, dilengkapi dengan format atau blangko pengamatan.

Wawancara dapat dilakukan secara terstruktur maupun tidak terstruktur, dan dapat dilakukan melalui tatap muka (face to face) maupun menggunakan telepon. Teknik tes tertulis digunakan untuk mengumpulkan data siswa yang berhubungan dengan penguasaan materi yang telah diajarkan oleh guru. Tes tertulis ini merupakan seperangkat pertanyaan yang disajikan kepada subyek penelitian dalam bentuk tertulis, baik pada kertas maupun komputer untuk menyelesaikan tugas kognitif.

Data yang tersaji dalam penelitian tindakan kelas ini dianalisis secara kuantitatif dan kualitatif. Analisa data kuantitatif digunakan rumus Paired Sample T-Test, yang merupakan prosedur digunakan untuk membandingkan rata-rata dua variabel dalam satu group. Prosedur Paired Samples Uji $T$ digunakan untuk menguji bahwa tidak atau adanya 
perbedaan antara dua variabel. Dalam perhitungan manual Paired-sample t-Test menggunakan rumus sebagai berikut :

$$
\mathrm{t}_{\text {hitung }}=\frac{\left(\overline{\mathrm{x}}_{1}-\overline{\mathrm{x}}_{2}\right)-\left(\mu_{1}-\mu_{2}\right)}{\sqrt{\frac{\sigma_{1}^{2}}{\mathrm{n}_{1}}+\frac{\sigma_{2}^{2}}{\mathrm{n}_{2}}}}
$$

Sedangkan untuk analisa kualitatif, data dari yang diperoleh menggunakan teknik pengumpulan data yang bermacam-macam (triangulasi), dan dilakukan secara terusmenerus sampai datanya jenuh. Dengan pengamatan yang terus menerus tersebut mengakibatkan variasi data tinggi sekali. Data yang diperoleh pada umumnya adalah data kualitatif. ${ }^{14}$

\section{HASIL PENELITIAN DAN PEMBAHASAN}

\section{Hasil Penelitian}

\section{Kondisi Awal}

Sebelum mengadakan Penelitian Tindakan Kelas, peneliti lebih dahulu melakukan observasi dan pengumpulan data dari kondisi awal kelas yang akan diberikan tindakan yaitu kelas VIII SMP Negeri 17 Surakarta semester genap tahun pelajaran 2015/2016. Pengetahuan awal diperlukan untuk menentukan langkah yang sesuai dengan yang diharapkan oleh peneliti. Melalui data awal ini, peneliti akan

\footnotetext{
${ }^{14}$ Sugiyono, Metode Penelitian Pendidikan, Pendekatan Kuantitatif, Kualitatif, dan R\&D (Bandung. Alfabeta, 2009), 157
}

mengetahui perlu tidaknya diberi tindakan yaitu penerapan metode pembelajaran demonstrasi untuk meningkatkan pemahaman dan hasil belajar tentang sakramen Perjamuan Kudus. Data yang telah terkumpul ini sebagai bahan acuan bagi peneliti untuk mempertimbangkan benar atau tidaknya penerapan strategi pembelajaran demonstrasi pada materi sakramen perjamuan kudus.

\section{Siklus I}

Sebelum melaksanakan tindakan dalam siklus I, peneliti lebih dahulu melakukan perencanaan berdasarkan hasil refleksi pada kondisi pra siklus. Data-data yang didapatkan oleh peneliti pada pra siklus digunakan untuk menentukan langkah yang direncanakan pada Siklus I melalui inovasi pembelajaran dengan menggunakan metode demonstrasi pada materi Formula dan Lambang Perjamuan Kudus. Untuk mendeskrisikan tindakan penelitian dalam siklus I, peneliti melakukan perencanaan sebagai berikut:

\section{Perubahan Kegiatan Belajar}

Pada siklus I kegiatan belajar mengajar dengan menggunakan metode demonstrasi pada materi formula dan lambang Perjamuan Kudus. Selain itu peneliti juga memodifikasi metode pembelajaran yakni metode demonstrasi dimodifikasikan dengan metode diskusi. Kegiatan belajar 
yang dilaksanakan dengan metode demonstrasi berjalan baik dan sesuai dengan yang direncanakan. Salah satu faktor yang mendukung kegiatan belajar mengajar berjalan dengan baik, dimana metode demonstrasi membantu peserta didik untuk menghubungkan materi dengan kondisi kehidupan secara nyata. Peserta didik rata-rata menyatakan kegiatan belajar mengajar dengan menggunakan metode demonstrasi memudahkan peserta didik memahami formula dan lambang Perjamuan Kudus yang digunakan dalam ibadah sakramen Perjamuan Kudus di gereja. Selain itu, metode demonstrasi memudahkan peserta didik untuk memahami dan mengetahui secara jelas materi pembelajaran.

Peserta didik yang dulunya belum termotivasi dalam mengikuti pembelajaran Pendidikan Agama Kristen, dengan digunakannya metode demonstrasi terjadi perubahan motivasi pada peserta didik. Peserta didik mulai menyenangi kegiatan belajar Pendidikan Agama Kristen. Hal ini ditunjukkan dari sikap peserta didik dimana $64,7 \%$ peserta didik menyatakan senang terhadap materi pembelajaran formula dan lambang Perjamuan Kudus. Selain daripada itu peserta didik juga menyatakan senang terhadap suasana kelas yang terjadi interaktif aktif diantara peserta didik. Dimana $70,6 \%$ peserta didik menyatakan senang terhadap suasana kelas yang telah berubah menjadi kondusif dan interaktif aktif dan $70,6 \%$ peserta didik juga menyatakan senang terhadap kegiatan belajar mengajar di kelas.

\section{Perubahan pada Siswa}

Pada siklus I terjadi perubahan pada siswa ke arah cukup baik apabila dibanding pada kondisi pra siklus. Dari hasil capaian ketuntasan belajar siswa pada siklus I mengalami peningkatan di banding dengan kondisi pra siklus. Berdasarkan hasil capaian siklus I perlu melakukan analisa capaian range interval keberhasilan ketuntasan belajar maka peneliti melakukan analisa Decriptive Kriteria Ketuntasan Belajar Siklus I sehingga didapatkan gambar berikut ini:

Tabel 1: Decriptive

\begin{tabular}{|c|c|c|c|c|}
\hline \multicolumn{5}{|c|}{ Descriptives } \\
\hline & & & Statistic & Std. Error \\
\hline \multirow{13}{*}{$\begin{array}{c}\text { Kriteria } \\
\text { Ketuntasan } \\
\text { Belajar } \\
\text { Siklus I }\end{array}$} & \multicolumn{2}{|c|}{ Mean } & 74.12 & 1.254 \\
\hline & \multirow{2}{*}{$\begin{array}{c}95 \% \\
\text { Confidence } \\
\text { Interval for } \\
\text { Mean }\end{array}$} & $\begin{array}{l}\text { Lower } \\
\text { Bound }\end{array}$ & 71.46 & \\
\hline & & $\begin{array}{l}\text { Upper } \\
\text { Bound }\end{array}$ & 76.78 & \\
\hline & \multicolumn{2}{|c|}{$5 \%$ Trimmed Mean } & 74.35 & \\
\hline & \multicolumn{2}{|c|}{ Median } & 75.00 & \\
\hline & \multicolumn{2}{|c|}{ Variance } & 26.735 & \\
\hline & \multicolumn{2}{|c|}{ Std. Deviation } & 5.171 & \\
\hline & \multicolumn{2}{|c|}{ Minimum } & 64 & \\
\hline & \multicolumn{2}{|c|}{ Maximum } & 80 & \\
\hline & \multicolumn{2}{|c|}{ Range } & 16 & \\
\hline & \multicolumn{2}{|c|}{ Interquartile Range } & 10 & \\
\hline & \multicolumn{2}{|c|}{ Skewness } & -.418 & .550 \\
\hline & \multicolumn{2}{|c|}{ Kurtosis } & -.982 & 1.063 \\
\hline
\end{tabular}


Dari hasil tabel di atas didapatkan tabel capaian Kriteria Ketuntasan Belajar Siklus I berikut:

Tabel 2

Capaian Kriteria Ketuntasan Belajar Siklus I

\begin{tabular}{|c|c|c|}
\hline Interval & Kategori Capaian & Keterangan \\
\hline $64-69$ & $\begin{array}{c}\text { Capaian KKM } \\
\text { Belajar Siklus I } \\
\text { Rendah }\end{array}$ & \\
\hline $70-75$ & $\begin{array}{l}\text { Capaian KKM } \\
\text { Belajar Siklus I } \\
\text { Sedang }\end{array}$ & \multirow{2}{*}{$\begin{array}{c}71,46- \\
76,78 \\
\text { (sedang } \\
\text { menuju ke } \\
\text { tinggi) }\end{array}$} \\
\hline $76-80$ & $\begin{array}{c}\text { Capaian KKM } \\
\text { Belajar Siklus I } \\
\text { Tinggi }\end{array}$ & \\
\hline
\end{tabular}

Dengan memperhatikan capaian ketuntasan hasil belajar pada siklus I, guru berusaha melakukan inovasi pembelajaran dengan cara melakukan modifikasi metode pembelajaran yakni memodifikasi metode demonstrasi dengan metode diskusi. Melalui metode diskusi guru memberikan kesempatan kepada peserta didik untuk saling bertukar pendapat mengenai demonstrasi yang dilakukan guru. Selain itu peserta didik juga bertukar pendapat tentang materi pelajaran formula dan lambang Perjamuan Kudus.

\section{Perubahan pada Guru}

Pada siklus I terjadi perubahan pada guru ke arah cukup baik yang disebabkan oleh beberapa faktorseperti diterapkannya metode demonstrasi yang memudahkan guru dalam menyampaikan materi pembelajaran. Metode demonstrasi ini juga dimodifikasi dengan metode diskusi kelompok sehingga suasana kelas lebih mudah dikendalikan oleh guru, sedang memudahkan guru memusatkan perhatian siswa pada materi pembelajaran. Dimana $64,7 \%$ peserta menyatakan senang terhadap materi yang disampaikan guru melalui metode demonstrasi.

Faktor selanjutnya dimana guru berusaha cara mengajar, dimana rata-rata peserta didik menyatakan senang dengan cara guru mengajar yakni sebanyak 52,9\%. Faktor berikutnya adalah kegiatan belajar mengajar lebih kondusif, aktif dan interaktif. Hal ini dibuktikan bahwa sebanyak $70,6 \%$ peserta didik menyatakan senang terhadap kegiatan belajar mengajar. Berdasarkan kondisi pada siklus I yang belum memenuhi indikator keberhasilan (85\%) maka peneliti memandang perlu adanya tindakan penelitian selanjutnya.

\section{Siklus II}

Dari hasil pengamatan yang berdasarkan data observasi, wawancara, dokumen dan evaluasi hasil belajar maka peneliti mengadakan refleksi pada siklus II untuk digunakan sebagai bahan pertimbangan berhasil tidaknya penelitian yang dilakukan. Penelitian dikatakan berhasil apabila memenuhi atau di atas indikator keberhasilan penelitian, sedangkan penelitian dikatakan tidak berhasil apabila tidak memenuhi indikator keberhasilan dan perlu dilakukan tindak lanjut dalam siklus berikutnya. 


\section{Perubahan Kegiatan Belajar Mengajar}

Pada siklus II kegiatan belajar mengajar dengan menggunakan metode demonstrasi pada materi makna dan prosesi ibadah Perjamuan Kudus. Guru mengajar dengan menggunakan metode demonstrasi yang dimodifikasi dengan metode diskusi kelompok, dengan pendekatan tanya jawab, curah pendapat, umpan balik, dan penugasan baik secara pribadi maupun kelompok. $94,1 \%$ peserta didik menyatakan senang terhadap materi pembelajaran, karena mereka ingin tahu prosesi ibadah Perjamuan Kudus yang didemontrasikan oleh guru. Sikap keingintahuan peserta didik yang demikian menumbuhkan sikap kritis dan fokus terhadap pembelajaran.

Sebanyak $100 \%$ atau keseluruhan peserta didik menyatakan senang dengan cara guru mengajar. Cara guru mengajar secara kreatif dan inovatif. Pola pengajaran dengan metode demonstrasi yang dimodifikasi dengan metode diskusi kelompok diperkaya lagi dengan pendekatan tanya jawab, curah pendapat, umpan balik dan penugasan baik pribadi maupun kelompok.

Suasana kelas yang begitu mendukung dan kondusif sehingga tercipta iklim belajar yang sehat. Peserta didik sebanyak $88,2 \%$ menyatakan senang terhadap iklim kelas yang sehat. Faktor berikutnya adalah kegiatan pembelajaran yang disenangi oleh keseluruhan peserta didik. Sikap antusias dan keaktifan dalam belajar di kelas semakin meningkat baik. Dalam kegiatan pembelajaran yang semakin diperkaya metode dan pendekatannya semakin menambah pengetahuan dan pengalaman peserta didik terhadap kondisi nyata kehidupan.

Berdasarkan capaian hasil belajar pada siklus II yang memberikan deskripsi tentang perubahan kegiatan belajar mengajar secara rata-rata prosentase sebesar $88,2 \%$ - 100\%, ini berarti telah melampaui indikator keberhasilan $85 \%$. Dengan memperhatikan hasil siklus II yang telah melampaui target pencapaian lebih dari indikator keberhasilan yakni $85 \%$ maka peneliti memandang penelitian tindakan kelas pada perubahan kegiatan belajar mengajar dikategorikan berhasil.

\section{Perubahan pada Siswa}

Pada siklus II adanya perubahan siswa yang semakin lebih baik jika dibanding dengan siklus I. Perubahan pada siswa dikarenakan peserta didik menyatakan senang terhadap sikap fair guru dalam menilai. Sebanyak $88,2 \%$ peserta didik menyatakan senang dengan cara penilaian guru. Cara penilaian guru yang benar ini membuat daya saing pencapaian hasil belajar berjalan dengan sehat dan fair.

Berdasarkan evaluasi belajar siklus II diperoleh rata-rata kelas 80,6 dimana di atas 
rata-rata KKM mata pelajaran Pendidikan Agama Kristen $(\mathrm{KKM}=75)$. Dari peserta didik yang berjumlah 17 orang, 15 peserta didik mendapatkan nilai $\geq$ KKM (sama dengan lebih besar dari KKM), sedangkan 2 peserta didik mendapatkan nilai di bawah KKM. Dengan demikian rata-rata tingkat keberhasilan siswa dalam mencapai ketuntasan belajar sebesar $88,2 \%$ ini berarti $3,2 \%$ di atas indikator keberhasilan belajar. Dari hasil ketuntasan belajar siswa pada siklus II mengalami peningkatan signifikan dibandingkan dengan kondisi siklus I. Berdasarkan hasil capaian siklus II perlu melakukan analisa capaian range interval keberhasilan ketuntasan belajar maka peneliti melakukan analisa Decriptive Kriteria Ketuntasan Belajar Siklus II sehingga didapatkan tabel berikut:

Tabel 3

\begin{tabular}{|c|c|c|c|c|}
\hline \multicolumn{3}{|c|}{ Descriptives } \\
\hline \multirow{4}{*}{} & \multicolumn{3}{|c|}{ Statistic } & Std. Error \\
\cline { 2 - 5 } & $\begin{array}{c}\text { M5\% } \\
\text { Confidence }\end{array}$ & Lower Bound & 80.82 & .810 \\
\cline { 2 - 4 } & $\begin{array}{c}\text { Interval for } \\
\text { Mean }\end{array}$ & Upper Bound & \\
\cline { 2 - 5 } & 5\% Trimmed Mean & 84.54 & \\
\cline { 2 - 5 } Kriteria & \multicolumn{2}{|c|}{ Median } & 81.03 & \\
\cline { 2 - 5 } Ketuntasan \\
\cline { 2 - 5 } Belajar & \multicolumn{2}{|c|}{ Variance } & 11.154 & \\
\cline { 2 - 5 } & \multicolumn{2}{|c|}{ Std. Deviation } & 3.340 & \\
\cline { 2 - 5 } & \multicolumn{2}{|c|}{ Minimum } & 73 & \\
\cline { 2 - 5 } & \multicolumn{2}{|c|}{ Maximum } & 85 & \\
\cline { 2 - 5 } & Range & 12 & \\
\cline { 2 - 5 } & \multicolumn{2}{|c|}{ Interquartile Range } & 3 & \\
\cline { 2 - 5 } & \multicolumn{2}{|c|}{ Skewness } & -1.526 & .550 \\
\cline { 2 - 5 } & Kurtosis & 2.210 & 1.063 \\
\hline
\end{tabular}

Siklus II sehingga didapatkan tabel 4.30. di bawah ini.

Tabel 4 Capaian Kriteria

Ketuntasan Belajar

\begin{tabular}{|r|c|c|}
\hline Interval & Kategori Capaian & Keterangan \\
\hline $73-77$ & $\begin{array}{c}\text { Capaian KKM } \\
\text { Belajar Siklus II } \\
\text { Rendah }\end{array}$ & \\
\hline $78-82$ & $\begin{array}{c}\text { Capaian KKM } \\
\text { Belajar Siklus II } \\
\text { Sedang }\end{array}$ & \\
\hline $83-85$ & $\begin{array}{c}\text { Capaian KKM } \\
\text { Belajar Siklus II } \\
\text { Tinggi }\end{array}$ & $\begin{array}{c}83,01-84,54 \\
\text { (tinggi) }\end{array}$ \\
\hline
\end{tabular}

\section{Perubahan pada Guru}

Pada siklus II perubahan pada guru semakin mengalami peningkatan apabila dibandingkan dengan siklus $I$, hal ini disebabkan oleh beberapa faktor. Faktor utamanya adalah, dikarenakan guru menggunakan metode demonstrasi yang dimodifikasi dengan metode diskusi serta digunakannya pendekatan tanya jawab, curah pendapat, umpa balik dan penugasan baik secara pribadi maupun kelompok. Dampak dari peningkatan kualitas mengajar guru dapat dilihat bahwa rata-rata untuk kegiatan mengajar guru sebesar 90,6\% menyatakan baik.

Materi pelajaran tentang makna dan prosesi ibadah Perjamuan Kudus yang disampaikan dengan menggunakan metode demonstrasi telah merangsang motivasi peserta didik untuk memiliki sikap senang terhadap materi pelajaran. Peserta didik 
dengan rata-rata prosentase $94,1 \%$ menyatakan senang terhadap materi pembelajaran. Tingkat prosentase $88,2 \%$ peserta didik yang menyatakan senang terhadap suasana kelas menunjukkan tingkat keberhasilan guru dalam menciptakan iklim belajar yang sehat. Guru dapat mengatasi keributan dalam kelas, guru dalam menangani peserta didik yang terlalu aktif sehingga peserta didik dapat fokus terhadap materi pelajaran. Terlebih lagi dalam demonstrasi prosesi ibadah Perjamuan Kudus, peserta didik secara sadar dan khidmat peserta didik mengikuti prosesi ibadah Perjamuan Kudus di kelas.

Berdasarkan kondisi pada siklus II perubahan guru terhitung sangat memuaskan dimana rata-rata prosentase keberhasilan guru dalam melaksanakan kegiatan belajar mengajar sebesar 90,6\%, hal ini di atas prosentase rata-rata indikator keberhasilan yang artinya penelitian tindakan telah berhasil melakukan perubahan pada guru.

\section{Hasil Belajar Kognitif}

Untuk mengetahui peningkatan hasil belajar bidang kognitif peserta didik sebelum tindakan dan setelah tindakan, maka dibuat rekapituasi nilai Pra Siklus, Siklus I, dan Siklus II sebagai berikut:

1. Pada pra siklus nilai rata-rata adalah 61,7 dengan demikian kondisi awal pada hasil belajar peserta didik adalah kategori cukup (60 - 69) dikarenakan $17,6 \%$ yang tuntas atau 3 orang yang mencapai ketuntasan belajar.

2. Pada siklus I, rata-rata hasil belajar yang diperoleh peserta didik adalah 74,2 termasuk dalam kategori baik (70 79) dikarenakan $47,1 \%$ yang tuntas atau sekitar 8 orang mencapai ketuntasan belajar.

3. Pada siklus II, rata-rata hasil belajar yang diperoleh peserta didik adalah 80,6 termasuk kategori sangat baik (80 - 100) dikarenakan $88,2 \%$ yang tuntas atau sekitar 15 orang mencapai ketuntasan belajar. Keberhasilan pencapaian ketuntasan belajar siswa lebih besar dari indikator keberhasilan yakni $85 \%$. Jadi pelaksanaan tindakan pada siklus II dinyatakan berhasil dalam mencapai ketuntasan belajar kognitif.

Berdasarkan data nilai yang diperoleh dari hasil evaluasi sebelum tindakan (pra siklus) dan setelah diadakan tindakan pada Siklus I dan Siklus II, dapat dibuat rekapitulasi nilai evaluasi pelajaran Agama Kristen peserta didik Kelas VIII SMP Negeri 17 Surakarta semester genap tahun pelajaran 2015/2016 adalah seperti ditunjukkan pada tabel berikut ini: 
Tabel 5: Rekapitulasi Hasil Belajar Materi Perjamuan Kudus Dengan Metode Demonstrasi

Peserta Didik Kelas VIII SMP Negeri 17

Surakarta Pra-Siklus, Siklus I, dan Siklus II

\begin{tabular}{|c|c|c|c|c|c|c|c|}
\hline \multirow{2}{*}{ No } & \multirow{2}{*}{ Nilai } & \multicolumn{2}{|c|}{ Pra Siklus } & \multicolumn{2}{c|}{ Siklus I } & \multicolumn{2}{c|}{ Siklus II } \\
\cline { 3 - 8 } & & N & Persen & N & Persen & N & Persen \\
\hline 1 & $\geq 80$ & - & $0,0 \%$ & 2 & $47 \%$ & 15 & $88,2 \%$ \\
\hline 2 & $70-79$ & 5 & $29,4 \%$ & 11 & $13 \%$ & 2 & $11,8 \%$ \\
\hline 3 & $60-69$ & 4 & $23,5 \%$ & 4 & $27 \%$ & - & $0,0 \%$ \\
\hline 4 & $50-59$ & 7 & $41,2 \%$ & - & - & - & $0,0 \%$ \\
\hline 5 & $\leq 49$ & 1 & $5,9 \%$ & - & $13 \%$ & - & $0,0 \%$ \\
\hline \multicolumn{2}{|c|}{ Jumlah } & 17 & $100 \%$ & 17 & $100 \%$ & 17 & $100 \%$ \\
\hline
\end{tabular}

Adapun rekapitulasi ketuntasan peserta didik dalam pembelajaran Pendidikan Agama Kristen materi Perjamuan Kudus melalui penerapan metode demonstrasi bagi siswa kelas VIII SMP Negeri 17 Surakarta pada semester 2 tahun pelajaran 2015/2016 dapat dilihat pada tabel di bawah ini:

Tabel 6: Rekapitulasi Ketuntasan Peserta didik Materi Perjamuan Kudusmelalui Penerapan Metode Demonstrasi Bagi Siswa Kelas

\begin{tabular}{|c|c|c|c|c|c|c|}
\hline \multirow{2}{*}{ Kriteria } & \multicolumn{2}{|c|}{ Pra Siklus } & \multicolumn{2}{|c|}{ Siklus I } & \multicolumn{2}{|l|}{ Siklus II } \\
\cline { 2 - 7 } & $\mathrm{N}$ & Persen & $\mathrm{N}$ & Persen & $\mathrm{N}$ & Persen \\
\hline $\begin{array}{c}\text { Tuntas } \\
\text { Nilai } \\
(\geq 85)\end{array}$ & 3 & $17,6 \%$ & 8 & $47,1 \%$ & 15 & $88,2 \%$ \\
\hline $\begin{array}{c}\text { Belum } \\
\text { Tuntas } \\
\text { Nilai } \\
(\leq 74)\end{array}$ & 14 & $82,4 \%$ & 9 & $52,9 \%$ & 2 & $11,8 \%$ \\
\hline Jumlah & 17 & $100 \%$ & 17 & $100 \%$ & 17 & $100 \%$ \\
\hline
\end{tabular}

Dari tabel 6 dapat dijelaskan,

1. Diperoleh hasil yang tidak memuaskan dimana 14 peserta didik $(82,4 \%)$ belum tuntas, karena nilai hasil belajarnya di bawah KKM, yaitu 75. Sedangkan peserta didik yang mencapai nilai di atas KKM sebanyak 3 peserta didik (17,6\%). Untuk itu perlu diadakan perbaikan pembelajaran dengan metode demonstrasi.

2. Hasil siklus I sebanyak 8 peserta didik $(47,1 \%)$ tuntas, sedangkan 9 peserta didik (52,9\%) peserta didik belum tuntas. Hal ini berarti ada peningkatan terhadap ketuntasan belajar peserta didik, namun masih di bawah $85 \%$, untuk itu perlu diadakan lagi perbaikan pembelajaran pada siklus II.

3. Hasil siklus II adalah sebanyak 15 peserta didik $(88,2 \%)$ tuntas, sedangkan 2 peserta didik $(11,8 \%)$ belum tuntas. Hal ini berarti ada peningkatan terhadap ketuntasan belajar peserta didik. Ketuntasan belajar $88,2 \%$ berada di atas $85 \%$ menandakan bahwa perbaikan pembelajaran pada siklus II dengan menggunakan metode demonstrasi dinyatakan berhasil.

\section{Hasil Belajar Bidang Afektif}

Peningkatan hasil belajar bidang afektif peserta didik sebelum tindakan dan setelah tindakan dijelaskan berikut ini:

Pra siklus hasil pencapaian afektif adalah 8,2\%, dengan demikian kondisi awal pada hasil belajar peserta didik adalah gagal dikarenakan berada di bawah indikator keberhasilan. Pada siklus I, hasil pencapaian secara afektif adalah $14,1 \%$ 
dengan demikian kondisi siklus I masih dikategorikan gagal dikarenakan 70,9\% di bawah indikator keberhasilan. Pada siklus II, rata-rata hasil belajar yang diperoleh peserta didik adalah $92,4 \%$ dengan demikian kondisi siklus II dikategorikan berhasil karena melampaui indikator keberhasilan yakni $7,4 \%$ di atas indikator keberhasilan. Jadi pelaksanaan tindakan pada siklus II dinyatakan berhasil dalam mencapai ketuntasan belajar afektif. Setelah diadakan tindakan pada Siklus I dan Siklus II, dapat dibuat rekapitulasi pencapaian secara afektif pelajaran Agama Kristen peserta didik Kelas VIIISMP Negeri 17 Surakarta semester genap tahun pelajaran 2015/2016 sebagai berikut:

Tabel 7: Rekapitulasi Pencapaian Afektif

\begin{tabular}{|c|c|c|c|}
\hline Indikator & $\begin{array}{c}\text { Prosentase } \\
\text { Pra Siklus }\end{array}$ & $\begin{array}{c}\text { Prosentase } \\
\text { Siklus I }\end{array}$ & $\begin{array}{c}\text { Prosentase } \\
\text { Siklus II }\end{array}$ \\
\hline $\begin{array}{c}\text { Kemampuan } \\
\text { afektif siswa } \\
\text { telah } \\
\text { mencapai } \\
85 \%\end{array}$ & $8,2 \%$ & $14,1 \%$ & $92,4 \%$ \\
\hline
\end{tabular}

Hasil pencapaian afektif peserta didik materi Perjamuan Kudus pada kondisi pra siklus mendapatkan prosentase $8,2 \%$. Ini berarti masih berada di bawah indikator keberhasilan afektif yakni $85 \%$.

Hasil pencapaian afektif peserta didik materi Perjamuan Kudus melalui penerapan metode demonstrasi pada kondisi siklus I mendapatkan prosentase $14,1 \%$. Dengan demikian terjadi peningkatan sebesar 5,9\%, kendati demikian masih di bawah indikator keberhasilan afektif yakni $85 \%$.

Hasil pencapaian afektif peserta didik materi Perjamuan Kudus melalui penerapan metode demonstrasi pada kondisi siklus II mendapatkan prosentase $92,4 \%$. Dengan demikian terjadi peningkatan sebesar $78,3 \%$, hasil pencapaian afektif pada siklus II melampaui indikator keberhasilan afektif yakni $85 \%$.

Hasil pencapaian afektif pada siklus II mengalami peningkatan dari hasil siklussiklus sebelumnya yaitu siklus I dan pra siklus. Jadi penerapan metode demonstrasi dalam mata pelajaran Pendidikan Agama Kristen dengan materi Perjamuan Kudus tiap aspek peningkatan pencapaiannya disajikan pada tabel 8 berikut:

\section{Tabel 8: Peningkatan Pencapaian Afektif Peserta didik Pra Siklus, Siklus I, dan Siklus II Materi Perjamuan Kudus Melalui Penerapan Metode Demonstrasi}

\begin{tabular}{|c|c|c|c|c|c|}
\hline $\mathrm{N}$ & Siklus & $\begin{array}{c}\text { Prosen } \\
\text { tase }\end{array}$ & $\begin{array}{c}\text { Pening } \\
\text { katan }\end{array}$ & $\begin{array}{c}\text { Indikator } \\
\text { Keberhasilan } \\
\text { Afektif }\end{array}$ & Selisih \\
\hline 1 & $\begin{array}{c}\text { Pra } \\
\text { Siklus }\end{array}$ & $8,2 \%$ & - & $85 \%$ & $(-76,8 \%)$ \\
\hline 2 & $\begin{array}{c}\text { Siklus } \\
\text { I }\end{array}$ & $14,1 \%$ & $5,9 \%$ & $85 \%$ & $(-70,9 \%)$ \\
\hline 3 & $\begin{array}{c}\text { Siklus } \\
\text { II }\end{array}$ & $92,4 \%$ & $78,3 \%$ & $85 \%$ & $7,4 \%$ \\
\hline
\end{tabular}

Data pada tabel 8 di atas merupakan rekapitulasi pencapaian afektif materi Perjamuan Kudus melalui penerapan 
metode demonstrasi pra siklus, siklus I, dan siklus II. Uraian tabel di atas dapat diketahui bahwa pada dasarnya dengan adanya proses pembelajaran dalam tindakan penelitian ini menunjukkan bahwa pencapaian afektif materi Perjamuan Kudus pada peserta didik Kelas VIII SMP Negeri 17 Surakarta mengalami peningkatan baik.

Hal ini menunjukkan peningkatan yang baik dari tahap pra siklus sampai dengan siklus II dalam pelaksanaan tindakan penelitian ini. Hasil pencapaian afektif peserta didik materi Perjamuan Kudus melalui penerapan metode demonstrasi telah melampaui indikator keberhasilan (85\%) yakni sebesar $92,4 \%$.

\section{Hasil Belajar Bidang Psikomotorik}

Untuk mengetahui peningkatan hasil belajar bidang psikomotorik peserta didik sebelum tindakan dan setelah tindakan, maka dibuat rekapituasi nilai Pra Siklus, Siklus I, dan Siklus II sebagai berikut:

Tabel 9: Rekapitulasi Hasil Belajar Bidang Psikomotorik Pra Siklus, Siklus I, \& Siklus II Materi Perjamuan Kudus Kelas VIII SMP Negeri 17 Surakarta

\begin{tabular}{|c|c|c|c|c|}
\hline \multirow{2}{*}{ No. } & \multirow{2}{*}{ Nama Kegiatan } & \multirow{2}{*}{$\begin{array}{l}\text { Pra } \\
\text { Siklus }\end{array}$} & \multicolumn{2}{|c|}{ Perbaikan Siklus } \\
\hline & & & I & II \\
\hline 1 & $\begin{array}{l}\text { Mengikuti ibadah Perjamuan Kudus } \\
\text { dengan khidmat }\end{array}$ & $17,6 \%$ & $35,3 \%$ & $82,4 \%$ \\
\hline 2 & $\begin{array}{l}\text { Melakukan doa permohonan } \\
\text { pengampunan dosa sebelum menerima } \\
\text { Perjamuan Kudus }\end{array}$ & $29,4 \%$ & $41,2 \%$ & $100,0 \%$ \\
\hline 3 & $\begin{array}{l}\text { Berdoa secara pribadi setelah } \\
\text { menerima sakramen Perjamuan Kudus }\end{array}$ & $23,5 \%$ & $29,4 \%$ & $76,5 \%$ \\
\hline 4 & $\begin{array}{l}\text { Memiliki komitmen bertingkah laku } \\
\text { baik setelah menerima sakramen } \\
\text { Perjamuan Kudus }\end{array}$ & $17,6 \%$ & $47,1 \%$ & $82,4 \%$ \\
\hline & Rata-rata & $22,1 \%$ & $38,2 \%$ & $85,3 \%$ \\
\hline
\end{tabular}

Berdasarkan tabel 9 di atas dapat dijelaskan perolehan data sebagai berikut:

Pada pra siklus pencapaian psikomotorik peserta didik materi Perjamuan Kudus sebesar 22,1dengan demikian kondisi awal pada hasil belajar peserta didik adalah gagal dikarenakan 62,9\%di bawah indikator pencapaian psikomotorik yakni $85 \%$.

Pada siklus I pencapaian psikomotorik peserta didik materi Perjamuan Kudus sebesar 38,2\%dengan demikian kondisi awal pada hasil belajar peserta didik adalah gagal dikarenakan 46,8\%di bawah 
indikator pencapaian psikomotorik yakni $85 \%$.

Pada siklus II pencapaian psikomotorik peserta didik materi Perjamuan Kudus sebesar 85,3\%dengan demikian kondisi awal pada hasil belajar peserta didik adalah gagal dikarenakan $0,3 \%$ di atas indikator pencapaian psikomotorik yakni $85 \%$.

Keberhasilan pencapaian psikomotorik peserta didik materi Perjamuan Kudus di atas indikator keberhasilan yakni $85,3 \%$. Jadi pelaksanaan tindakan pada siklus II dinyatakan berhasil dalam mencapai ketuntasan belajar psikomotorik.

Berdasarkan data nilai yang diperoleh dari hasil evaluasi sebelum tindakan (pra siklus) dan setelah diadakan tindakan pada Siklus I dan Siklus II, dapat dibuat rekapitulasi nilai evaluasi pelajaran Agama Kristen peserta didik Kelas VIIISMP Negeri 17 Surakarta semester genap tahun pelajaran 2015/2016 adalah sebagai berikut:

\section{Tabel 10}

Tabel 10: Rekapitulasi Pencapaian Psikomotorik Peserta Didik Materi Perjamuan Kudusmelalui Penerapan Metode Demonstrasi Bagi Siswa Kelas VIII SMP Negeri 17 Surakarta

\begin{tabular}{|c|c|c|c|}
\hline Indikator & $\begin{array}{l}\text { Prosentase } \\
\text { Pra Siklus }\end{array}$ & $\begin{array}{c}\text { Prosentase } \\
\text { Siklus I }\end{array}$ & $\begin{array}{c}\text { Prosentase } \\
\text { Siklus II }\end{array}$ \\
\hline $\begin{array}{c}\text { Kemampuan } \\
\text { Psikomotorik } \\
\text { siswa telah } \\
\text { mencapai 85\% }\end{array}$ & $22,1 \%$ & $38,2 \%$ & $85,3 \%$ \\
\hline
\end{tabular}

Dari tabel 10 di atas dapat dijelaskan sebagai berikut:

Hasil pencapaian psikomotorik peserta didik materi Perjamuan Kudus pada kondisi pra siklus mendapatkan prosentase $22,10 \%$. Ini berarti masih berada di bawah indikator keberhasilan psikomotorik yakni $85 \%$.

Hasil pencapaian psikomotorik peserta didik materi Perjamuan Kudus melalui penerapan metode demonstrasi pada kondisi siklus I mendapatkan prosentase $38,2 \%$. Dengan demikian terjadi peningkatan sebesar 16,1\%, kendati demikian masih di bawah indikator keberhasilan psikomotorik yakni $85 \%$.

Hasil pencapaian psikomotorik peserta didik materi Perjamuan Kudus melalui penerapan metode demonstrasi pada kondisi siklus II mendapatkan prosentase $85,3 \%$. Dengan demikian terjadi peningkatan sebesar 47,1\%, hasil pencapaian afektif pada siklus II melampaui indikator keberhasilan afektif yakni $85 \%$.

Hasil pencapaian afektif pada siklus II mengalami peningkatan dari hasil siklussiklus sebelumnya yaitu siklus I dan pra siklus.Jadi penerapan metode demonstrasi dalam mata pelajaran Pendidikan Agama Kristen dengan materi Perjamuan Kudus tiap aspek peningkatan pencapaiannya disajikan pada tabel 11 berikut: 
Tabel 11: Peningkatan Pencapaian Psikomotorik Peserta didik Pra Siklus, Siklus I, dan Siklus II Materi Perjamuan Kudus Melalui Penerapan Metode Demonstrasi

\begin{tabular}{|c|c|c|c|c|c|}
\hline $\begin{array}{c}N \\
0\end{array}$ & Siklus & $\begin{array}{c}\text { Prosen } \\
\text { tase }\end{array}$ & $\begin{array}{c}\text { Pening } \\
\text { katan }\end{array}$ & $\begin{array}{c}\text { Indikator } \\
\text { Keberhasilan } \\
\text { Psikomotik }\end{array}$ & Selisih \\
\hline 1 & $\begin{array}{c}\text { Pra } \\
\text { Siklus }\end{array}$ & $22,1 \%$ & - & $85 \%$ & $(-62,9 \%)$ \\
\hline 2 & $\begin{array}{c}\text { Siklus } \\
\text { I }\end{array}$ & $38,2 \%$ & $16,1 \%$ & $85 \%$ & $(-46,8 \%)$ \\
\hline 3 & $\begin{array}{c}\text { Siklus } \\
\text { II }\end{array}$ & $85,3 \%$ & $47,1 \%$ & $85 \%$ & $0,3 \%$ \\
\hline
\end{tabular}

Data pada tabel 4.42. di atas merupakan rekapitulasi pencapaian psikomotorik materi Perjamuan Kudus melalui penerapan metode demonstrasi pra siklus, siklus I, dan siklus II. Uraian tabel di atas dapat diketahui bahwa pada dasarnya dengan adanya proses pembelajaran dalam tindakan penelitian ini menunjukkan bahwa pencapaian psikomotorik materi Perjamuan Kuduspada peserta didik Kelas VIII SMP Negeri 17 Surakarta mengalami peningkatan baik.

Hal ini menunjukkan peningkatan yang baik dari tahap pra siklus sampai dengan siklus II dalam pelaksanaan tindakan penelitian ini. Hasil pencapaian psikomotorik peserta didik materi Perjamuan Kudus melalui penerapan metode demonstrasi telah melampaui indikator keberhasilan (85\%) yakni sebesar $85,3 \%$.
Berdasarkan temuan pada penelitian ini maka dapat diterangkan perkembangan dari sebelum perbaikan (pra siklus), siklus I, dan siklus II sebagai berikut:

\section{Uji Hipotesa Tindakan Pertama}

Hipotesis tindakan pertama mencoba menjawab penerapan metode demonstrasi dapat meningkatkan hasil belajar afektif peserta didik kelas VIII SMP Negeri 17 Surakarta. Pencapaian afektif peserta didik materi Perjamuan Kudus pada kondisi pra siklus mendapatkan prosentase $8,2 \%$. Ini berarti masih berada di bawah indikator keberhasilan afektif yakni $85 \%$.

Penerapan metode pembelajaran demonstrasi memberikan hasil pencapaian afektif peserta didik materi Perjamuan Kudus pada kondisi siklus I sebesar $14,1 \%$. Dengan demikian terjadi peningkatan sebesar $5,9 \%$, kendati demikian masih di bawah indikator keberhasilan afektif yakni $85 \%$.

Pada saat siklus II penerapan metode pembelajaran demonstrasi memberikan hasil pencapaian afektif peserta didik materi Perjamuan Kudus sebesar 92,4\%. Dengan demikian terjadi peningkatan sebesar 78,3\%, hasil pencapaian afektif pada siklus II melampaui indikator keberhasilan afektif yakni $85 \%$. 
Berdasarkan hasil penelitian ini maka hipotesis tindakan yang mengatakan "Penerapan metode demonstrasi dapat meningkatkan hasil belajar afektif materi Sakramen Perjamuan Kudus bagi peserta didik kelas VIII SMP Negeri 17 Surakarta semester 2 Tahun 2015/2016" terbukti kebenarannya.

\section{Uji Hipotesa Tindakan Kedua}

Hipotesis tindakan kedua mencoba menjawab penerapan metode demonstrasi dapat meningkatkan hasil belajar psikomotorik peserta didik kelas VIII SMP Negeri 17 Surakarta. Pada pra siklus pencapaian psikomotorik peserta didik materi Perjamuan Kudus sebesar 22,1 dengan demikian kondisi awal pada hasil belajar peserta didik adalah gagal dikarenakan 62,9\%di bawah indikator pencapaian psikomotorik yakni $85 \%$.

Pada siklus I pencapaian psikomotorik peserta didik materi Perjamuan Kudus sebesar 38,2\%dengan demikian kondisi awal pada hasil belajar peserta didik adalah gagal dikarenakan 46,8\% di bawah indikator pencapaian psikomotorik yakni $85 \%$.

Pada siklus II pencapaian psikomotorik peserta didik materi Perjamuan Kudus sebesar 85,3\%dengan demikian pada siklus II hasil belajar peserta didik adalah berhasil dikarenakan
$0,3 \%$ di atas indikator pencapaian psikomotorik yakni $85 \%$.

Berdasarkan hasil penelitian ini maka hipotesis tindakan yang mengatakan Penerapan metode demonstrasi dapat meningkatkan hasil belajar psikomotorik materi Sakramen Perjamuan Kudus bagi peserta didik kelas VIII SMP Negeri 17 Surakarta semester 2 Tahun 2015/2016" terbukti kebenarannya.

\section{Uji Hipotesa Tindakan Ketiga}

Hasil pembelajaran Pendidikan Agama Kristen Agama Kelas VIII materi Perjamuan Kudus pada kondisi awal diperoleh hasil yang tidak memuaskan yakni sebanyak $17,6 \%$ peserta didik dinyatakan tuntas. Pada hasil siklus I adalah sebanyak 9 peserta didik atau $52,9 \%$ peserta didik belum tuntas.

Sedangkan pada siklus II mendapatkan hasil sebanyak 15 peserta didik atau $88,2 \%$ tuntas. Hal ini berarti ada peningkatan terhadap ketuntasan belajar peserta didik. Ketuntasan belajar $88,2 \%$ yang berada di atas $85 \%$ menandakan bahwa perbaikan pembelajaran pada siklus II dengan menggunakan metode demonstrasi dinyatakan berhasil.

Berdasarkan hasil penelitian ini maka hipotesis tindakan yang mengatakan: "Penerapan metode demonstrasi dapat meningkatkan hasil belajar kognitif materi 
Sakramen Perjamuan Kudus bagi peserta didik kelas VIII SMP Negeri 17 Surakarta semester 2 Tahun 2015/2016" terbukti kebenarannya.

\section{KESIMPULAN}

Dari penelitian tindakan kelas yang telah dilaksanakan pada siswa kelas VIII SMP Negeri 17 Surakarta semester 2 Tahun 2015/2016, maka dapat ditarik kesimpulan sebagai berikut :

Pertama, dengan menggunakan metode demonstrasi dalam pembelajaran Agama Kristen dapat meningkatkan hasil belajar afektif materi materi Sakramen Perjmuan Kudus bagi siswa yang bersangkutan.

Kedua, dengan menggunakan metode demonstrasi dalam pembelajaran Agama Kristen dapat meningkatkan hasil belajar psikomotorik materi materi Sakramen Perjmuan Kudus bagi siswa yang bersangkutan.

Ketiga, dengan menggunakan metode demonstrasi dalam pembelajaran Agama Kristen dapat meningkatkan hasil belajar kognitif materi materi Sakramen Perjmuan Kudus bagi siswa yang bersangkutan.

\section{REKOMENDASI}

Setelah mengadakan penelitian tindakan kelas pada siswa kelas VIII SMP Negeri 17 Surakarta semester 2 Tahun
2015/2016 maka penelitian ini merekomendasikan:

Pertama, bagi siswa: Melalui penelitian ini siswa memotivasi diri untuk mencapai hasil belajar dengan maksimal dan melakukan ibadah sakramen Perjamuan Kudus di gerejanya masingmasing dengan khidmat.

Kedua, bagi guru: Melalui penelitian ini diharapkan guru mampu mengembangkan model pembelajaran lainnya yang lebih berorientasi pada proses dan hasil sehingga kualitas pembelajaran meningkat.

Ketiga, bagi sekolah: Melalui penelitian ini diharapkan sekolah dalam hal ini pimpinan sekolah mampu memotivasi guru untuk melakukan inovasi pembelajaran dan memotivasi untuk selalu melakukan inovasi dengan metode belajar dan model pembelajaran yang lain.

Keempat, bagi kolaborator: Melalui penelitian ini Kolaborator bersedia menggunakan pengalaman dan pengetahuan ini sebagai wacana bagi kolaborator untuk melakukan penelitian yang sejenis. 


\section{REFERENSI}

Andayani, Problema dan Aksioma. Yogyakarta: Penerbit Deepublish, 2015

Anas, Muhammad. 2015. Mengenal Metode Pembelajaran. Dilansir dari google books.

Aliansyah, M. 2012.,Penerapan Metode

Demonstrasi Untuk Meningkatkan Hasil Belajar Matematika Pada Materi Volume Balok di Kelas V Sekolah Dasar Negeri 06 Riam Danau Kecamatan Jelai Hulu Kabupaten Ketapang. Program Studi Pendidikan Guru Sekolah Dasar Jurusan Pendidikan Dasar. Universitas Tanjungpura Pontianak., Fakultas Keguruan dan Ilmu Pendidikan. Arifin,Zaena. 1990. Evaluasi

Instruksional Prinsip Teknik Prosedur. Bandung : Remadja Karya Erlangga, Aden., Dantes. Kadek

Rihendra., Nurhayata, I Gede.

"Pengaruh Metode Pembelajaran Demonstrasi Terhadap Minat Belajar Siswa Kelas X Teknik Instalasi Tenaga Listrik Pada Sub Kompetensi Melakukan Pekerjaan Mekanik Dasar di SMK Negeri 3 Singaraja", $\boldsymbol{e}$ Journal JJPTE, Vol. 3, 2014.

Kurniawan. Pebli Vidia, Penerapan Metode Demonstrasi Berbantuan Alat Peraga Untuk Meningkatkan Minat dan Motivasi Siswa dalam Pembelajaran Fisika, Semarang: SMP Purnama 3.

Sudjana, Nana. 2009. Dasar-dasar Proses

Belajar Mengajar. Bandung: Sinar Baru Algensindo. 1995. Penilaian Hasil

Proses Belajar Mengajar. Bandung :

PT Remaja Rosdakarya.
Sugiyono.2009. Metode Penelitian Pendidikan, Pendekatan Kuantitatif, Kualitatif, dan R\&D. Bandung. Alfabeta

Suryadi, Didi. 1997. Alat Peraga dan Pengajaran Ilmu Pengetahuan Alam. Jakarta: Ditjen Dikdasmen D2 Karunika UT.

Surya, Yohanes. 1997.Olympiade.Jakarta : Galaxy.

Suyatno, 2009.Menjelajah Pembelajaran Inovatif. Jawa Timur: Masmedia Buana Pustaka.

Suyanto \& Jihad,Asep.Menjadi Guru Profesional.Jakarta: Esensi Erlangga, 2013

Suyono dan Hariyanto, 2011.Belajar dan Pembelajaran. Bandung: PT Remaja Rosdakarya.

Syah, Muhibbin. 2010. Psikologi Pendidikan. Bandung: PT Remaja Rosdakarya.

Tim Pengembang Ilmu Pendidikan FIP UPI, 2007. Ilmu dan Aplikasi Pendidikan.4 Bagian. Pendidikan Disiplin Ilmu., Grasindo

Wibawa, Cahya. "Perbedaan Efektifitas Metode Demonstrasi Dengan Pemutaran Video Pemberantasan DBD Terhadap Peningkatan Pengetahuan dan Sikap Anak SD di Kecamatan Wedarijaksa Kabupaten Pati”, Jurnal Promosi Kesehatan Indonesia, Vol. 2, No.2, Agustus, 2007 